\title{
Assessing the Role of Training in Growing Women Small Business Holdings in Dansoman Market of Ghana
}

\author{
Georgina Ansong \\ Independent Scholar, Chief Financial Officer of Beautiful Creation Group of Company of Accra, Accra, Ghana \\ Email: ginasong2001@yahoo.com
}

How to cite this paper: Ansong, G. (2021). Assessing the Role of Training in Growing Women Small Business Holdings in Dansoman Market of Ghana. Journal of Human Resource and Sustainability Studies, 9, 317-336.

https://doi.org/10.4236/jhrss.2021.92020

Received: May 12, 2021

Accepted: June 22, 2021

Published: June 25, 2021

Copyright ( 2021 by author(s) and Scientific Research Publishing Inc. This work is licensed under the Creative Commons Attribution International License (CC BY 4.0).

http://creativecommons.org/licenses/by/4.0/ (c) (i) Open Access

\begin{abstract}
The study examined how training and development packages can be extended to women small scale businesses of Ghana especially Dansoman Market in the Metropolitan Accra Region. The study was motivated by the fact that a good number of small women business owners who are single mothers or bread winners, often lose their profit and capital through reckless expenditure pattern such as employing them to acquire parcels of land, flashy vehicles which can all be obtained with long term credits rather than damage their liquidity positions. In conducting the qualitative study, stratified random sampling technique was adopted to select traders in various product segments within the Dansoman market. Purposive sampling technique assisted the study in soliciting information from financial institutions in the area which transact financial businesses with a good number of these traders. It came out unequivocally from the study that most of the women traders have no training whatsoever in financial, marketing nor human resource management and that they are virtually practicing what they see others do and pick up from friends. The study therefore recommended that stakeholders especially government agencies like Ministry of Trade and Industry, Women and Children Affairs, National Board for Small Scale Industries (NBSSI) as well as Ghana Association of Bankers collaborate and evolve a suitable kind of training packages for these women traders thereby enhancing their managerial competence towards sustaining a mutually beneficial business relationship.
\end{abstract}

\section{Keywords}

Training and Development, Semi Illiterate Traders, Women Traders, Working Capital Management, Poverty Reduction 


\section{Introduction}

Training according to Daft (2006) constitutes an essential element in business administration which enables managers to acquire contemporary knowledge and skills needed to translate their business plans into effective practical structures thereby enhancing the suitability of a manager to withstand competition in a highly competitive business environment. Operators of all kinds of businesses therefore need training to acquire new knowledge as well as develop their skills from time to time so as to adopt best practices in the industry to leverage on both human and working capital towards registering a better return on business owners' investment.

Central Government of Ghana is getting increasingly disturbed about the frequent manner in which small businesses especially owned by Ghanaian women, most of whom are single mothers or nuclear family bread winners and the process damage the economic power of the families leading to neglect of the upkeep of the children and for that matter augment abject poverty levels in the country. Government therefore sees small business operations as a potential avenue where people can be empowered to enhance wealth creation as well as equity distribution of the national cake. It is from this background that central government through the NBSSI is making frantic efforts to stimulate small, table top and medium scale businesses through concessionary rated credits payable over relatively longer period of time.

This idea has been partly necessitated by the adverse effect of COVID-19 on economic fortunes of businesses. With all these business enhancement facilities in place if the traders especially women did not wield the requisite knowledge and skills to operate their businesses successfully, such funds are likely to be misapplied thereby defeating government policy of growing the informal sector businesses to improve if not maintain the existing status of the country as a middle income one with the per capita income of over $\$ 1200$. The study therefore examines how training and development packages can be extended to the informal sectors of the economy of Ghana especially women in small businesses so as to build their capacity to sustain the enterprises and contribute their quota towards addressing the socio-economic aspiration of the country. Essentially the study is predicated on specific objective such as:

- To examine the training and skills development needs of Dansoman market women.

- To explore avenues through which such training needs can be implemented.

- To sensitize small business holders about the importance of training.

- Identify challenges associated with conducting training and skills development activity for Dansoman traders.

To achieve the afore mention objectives the study examines contemporary literature on training and skills development activities meted out to small scale women businesses in the western jurisdiction as well as Asia and some African countries prior to discussing the research methodology, findings and discus- 
sions, in addition to drawing conclusions and making appropriate recommendations.

\section{Literature Review}

This segment examines training and development packages exposed to smalls businesses in the Western world, Far East countries as well as some African countries. It begins with studies from North America.

\subsection{Training and Development Packages for Small Businesses in America}

Estimates by Muller et al. (2015) point to the fact that, the U.S alone has over 20 million micro-businesses and that microbusiness jobs constitute $16.6 \%$ of all private (non-farm) employment in that country. Microbusinesses, the source explains do not engage more than five employees and that, these smaller businesses do not control more than $\$ 35,000$ working capital levels. Majority of them too, do not have the capacity to access credits directly from the traditional banks for starting up purposes. Much earlier studies by Salas et al. (2012) and Lancaster and Di Milia (2014) identified two dichotomous factors that motivated self-employment which they mentioned as "pull" and "push" factors. By way of explanation, "pull factors" to refer to those that convince the individual that, engaging in self-employment could confer some reasonable element of flexible working hours which confer some huge autonomy and also challenges the individual to work through competition and be on top of the industry (Bakker, 2017).

On the other hand, "push factors" describe those that render working in traditional economy non-attractive because there seems to be some stagnation with respect to personal career advancement and also achieving other individual aspirations (Lancaster and Di Milia, 2014). In the opinion of Montani et al. (2014), generally, "pull factors" have to do with self-fulfillment proud social status, independence and being one's own boss. Profitability was also seen by Salas et al. (2012) as a "pull factor" for attracting individuals to get involved in self-employment.

Those who promote the "push factor" as a motivator for going into private business saw inadequate income from family, insufficient salary from current occupation, work boredom as well as difficulty in finding white collar jobs are all seen by Montani et al. (2014) as the real factors that push individuals into private entrepreneurship. Further studies in the western world mentioned the fact that a good number of women are pushed into starting their own businesses owing to pay dissatisfaction as well as discrimination in gender. A survey by Muller et al. (2015), uncovered the fact that $44 \%$ of businesses owned by women pointed out that, they had to establish their own businesses because they felt marginalized at their previous work places and this meant some kind of humiliation which they could hardly condone. Bakker (2017) also found out from a survey involving 600 women that, $58 \%$ of them left their pervious traditional sector businesses and 
vowed never to reenter corporations dominated by men.

In his article on "training women for success", Bauer (2007) observes that, women are increasingly becoming essential players in the micro business sector in the economy of United State where it is estimated that women own $40 \%$ of small businesses (Muller et al., 2015). Taking cognizance of the growing importance of small businesses of the economy the source explains that it is essential to expose women and others to training and skills development packages so as to help them succeed. Bell et al. (2017) are of the view that, although self-employment requires no advanced education, there is the need to expose operators to a set of personal and technical skills which means some kind of training must be given to operators so as to build their competent towards enhancing their business prospect. In the opinion of Cardon and Valentin (2017), welfare assistance by way of technical training and loans often go a very long way to help small business entrepreneurs to commence as well as formalize operations and expand their business horizons.

Studies by Bakker (2017) and Grossman and Salas (2011) all point to the fact that micro-business enhancement packages like “Women's Small Business Program" and the "Micro-Business Development Program" are all effective strategies for enhancing small business prospects in developed economies like the United State (US). Studies conducted by Thom (2015) employing 140 small business volunteers in the US indicated that, after receiving training in entrepreneurship, over $50 \%$ of the respondents noted that, they had effectively established their own businesses and that twenty-five percent had begun reaping profits from their undertakings. This clearly indicates that appropriate training in entrepreneurship goes a long way to assist first timers begin and sustain their business operations.

\subsection{Training Women in Small Businesses in Far East}

Statistics by De Jong and Den Hartog (2010) points to the fact that, in every eleven women in Far East countries, one ventures into business representing 8.9\% especially in India. This ranks second in that region of 22 countries where $14.1 \%$ women have established one kind of business or the other. Women who enter into technology based businesses according to Ongori \& Nzonzo (2011) grow their outfit faster than those who operate traditional method of running business. Making a comparison between female owned businesses and male businesses Grossman \& Salas (2011) notes that, generally women's businesses grow at a slower pace than those of their male counterparts.

This issue of women being slow at growing their businesses according to $\mathrm{Li}$ (2012) is a serious setback which can be corrected through appropriate capacity building mechanisms. External fund providers according to Yang et al. (2005) frown upon women business owners who they feel are having credibility gap as far as repayment of funds are concerned. Entrepreneurship in China has been or particularly important in the socio-economic growth in the country since ade- 
quate structures have been put in place to encourage Chinese SME's to grow. Funding capacity building in financial management, book keeping, customer care, marketing management are all essential areas that have been emphasized in capacity building exercise for the India woman to grow.

This line of action Cho and Honorati (2014) has created a good number of town and village enterprises which are the brain behind Chinese economy today. According to Yang et al. (2005), the local government of china plays a key role in assisting and facilitating the development of women entrepreneurship in India through Town and Village Enterprise (TVE). In another study, it was discovered that, the access of interest in some decentralized governance structures continues to inhabit the growth of some women enterprises in India (Idawatil et al., 2016).

\subsection{Views from South Africa and Nigeria}

Taking cognizance of the importance of informal sector business activities to the socio-economic development of Africa, the study deemed appropriate to take a good look at a few studies conducted in Nigeria and South Africa.

\subsubsection{Nigeria}

In the view of Eniola \& Entebang (2014) training and skills development offered to individual small holder businesses has the propensity of enhancing their competitiveness in an ever growing keenly contested market place. The source explains further that, it enables business owners and managers of these businesses to acquire bespoke skills thereby broadening the horizon of their businesses. Ikupolati et al. (2017) also emphasized that knowledge acquisition emanates through training thereby enabling entrepreneurs to acquire more networks as well as transfer technology to strengthen their managerial capabilities.

In the opinion of Idawatil et al. (2016) training affords small business holders in Nigeria the opportunity of acquiring new business skills and other innovative practices which all inure to the benefit of the enterprises. On his path, Ayodeji (2015) pointed out that, skills development and training helps small business holders on the African continent to gather skills necessary to improve upon "ground breaking business plans" and other models.

\subsubsection{South Africa}

Studies by Littlewood and Holt (2018) pointed out that skills development and training offered to small and medium scale enterprises in South Africa help the employees as well as business owners to augment their organizational and inter personal skills, as well as knowledge and abilities which are essential requisite for building competence and gaining competitive advantage at the market place. Writing on the importance of capacity building packages for small business holders, Mamabolo et al. (2017) noted that, small organizations are not enthused at providing formal training to their employees for various reasons notably lack of time, extra cost, for fear of staff turnover among others. The source further 
noted that, for small businesses to grow, trade associations, chamber of commerce, bankers association and other direct institutions that benefits from these small businesses should come together and provide some kind of logistical support to enable skills and training sections to be conducted the more affordable manner.

\section{Research Methodology}

The Dansoman market which is at South West of Accra, is a cosmopolitan one which has been segmented into product types like fish/meat sellers, foodstuffs, dairy products, electronics, cook food sellers, baby care, building materials among others. The study therefore considered these products units as strata in which samples were selected using random sampling technique for soliciting information for addressing the objectives of the study. Descriptive research design was adopted to facilitate assessing of primary data to strategize the direction of the study

Random sampling technique can therefore be said to have been liaised up with stratified sampling towards picking up the sampling size of 120 for the study out of the 459 women small business holders at the Dansoman market. Purposive sampling technique was however used to directly select some market queens and managers of the market for their views of some pertinent topics. The interview guide was deemed appropriate for gathering information from the respondents since a good number of them are semi-illiterates and will have challenges with answering questions posed by a questionnaire.

The interview guide, which was designed in consonance with the objectives of the study, afforded the research assistants the opportunity of recording responses made from respondents who had challenges with reading and writing. As a qualitative research approach, the interview guide had 5 sections. Section A examined the demography of respondents, while Section B was devoted towards objective 1 i.e. examining the training needs of the women small holder businesses at the Dansoman market. Section C investigated how training packages could be administered to the various category of traders some of whom are stack illiterates, while others semi illiterates and a few further educated. Section D sought to create awareness among the women traders to the needs to be better equipped with modern trends in buying and selling so as to properly leverage on their working capital. The last Section E attempted to identify the challenges that will bedevil efforts at exposing the women small business holders to training and skills development packages.

In all 120 respondents were interviewed employing the interview guide. The study employed the Slovin's formula for calculating minimal sample i.e. $\mathrm{n}=$ $\mathrm{N} /\left(1+\mathrm{Ne}^{2}\right)$, where $\mathrm{n}$ is the sample size, $\mathrm{N}$ is the population size and e i.e. the margin of error used. Out of the 459 traders at the Dansoman market. Approximately on the average, 35 minutes were spent on interviewing each respondent. Owing to the similarity in answers, there was the need to employ the Statistical Package for Social Science (SPSS) version 20 to assist in ranking as well as get- 
ting the mean scores and standard deviation of the various responses from the interviewees. One hundred twenty (120) respondents out of 459 i.e. $26.1 \%$ sample size, from all indications is a reliable sample size for generalizing the findings of the study. It is the conviction of the researcher that if different researchers were given same research instrument to conduct the study, the findings will not be different from what have been reported here and therefore the validity of the study can be said to be upright. Under no circumstance was any respondent coerced or placed under duress to answer any question. The respondent consented to participating in the study out of their own free will and therefore the ethical uprightness of the study cannot be in doubt.

\section{Limitations of the Study}

Ghana currently has 154 decentralized governance structures which are either Metropolitan, Municipal or District Assemblies and all these have numerous market with semi-illiterate traders who have challenges with properly managing their businesses and for that matter also require training. Using Dansoman market alone which is the main market in one municipality i.e. Ablekuma West therefore presupposes that information for the study may not be enough to meet the objectives of the study. Most trader-participants were initially skeptical at participating since they thought government was behind the study with the intention of ascertaining their profits margins for imposing higher tax obligations. The researcher and her assistants endeavoured to convince them that the study was not only for academic purpose but also had the propensity of sensitizing stakeholders to assist them with training, possibly free of charge and for that matter they should be forthright with their answers. This assisted in disabusing their mind of any tax enhancement connotations behind the study and therefore the participants freely volunteered their responses. Dansoman market has a trader base from different ethnic groups in Ghana and therefore some responses were in languages like Ewe, Gusasi, Hausa, Nzema, Ahanta, Krobo, Larteh, which were difficult to translate and therefore the researcher had to hire people who really understood the language to help with the translation. Despite all these limitations, the study was poised to come up with the final report that will not only stand the test of the time but also meet the set objectives.

\section{Findings}

Respondents' reaction to the research questions in respect of the study to investigate the training needs of Dansoman market traders in Accra Ghana have been presented hereunder and arranged in the order of the objectives of the study.

\subsection{Objective One i.e. Examining the Training and Skills Development Needs of Dansoman Market Women}

Packaged in Table 1 are the findings in respect of these concerning the training and development needs of the respondents. 
Table 1. Frequency table examining the training and skills development needs of Dansoman market women.

\begin{tabular}{|c|c|c|c|c|c|}
\hline Statements & $\mathrm{N}$ & Mean & STD Dev & Variance & Rank \\
\hline $\begin{array}{l}\text { Most women traders inherited the business from their parents and } \\
\text { for that matter had no formal training whatsoever in financial } \\
\text { management, marketing or customer care. }\end{array}$ & 120 & 4.07 & 0.889 & 0.790 & 1 \\
\hline $\begin{array}{l}\text { Some women traders felt the need to help their husbands to } \\
\text { support the family, thereby starting to sell on the market } \\
\text { without formal training. }\end{array}$ & 120 & 3.93 & 0.708 & 0.501 & 2 \\
\hline $\begin{array}{l}\text { A few women also felt they were not attracting husbands because } \\
\text { of low education and poor financial circumstances so had to start } \\
\text { selling as means of gathering some money with the view to } \\
\text { enticing men as life partners. }\end{array}$ & 120 & 3.79 & 0.865 & 0.749 & 3 \\
\hline $\begin{array}{l}\text { Owing to low level of education, some women traders refuse to } \\
\text { accept higher denominations of currency notes like the } \mathrm{GH} ₫ 50.00 \text {, } \\
\mathrm{GH} \$ 100.00, \mathrm{GH} \$ 200.00 \text { and for that matter will need training } \\
\text { in basic mathematics. }\end{array}$ & 120 & 3.64 & 0.901 & 0.811 & 4 \\
\hline $\begin{array}{l}\text { Some parents felt their daughters were not serious at school } \\
\text { and therefore found some money to help them trade so as } \\
\text { to irk a living without any training. }\end{array}$ & 120 & 3.57 & 0.909 & 0.826 & 5 \\
\hline
\end{tabular}

Source: (Georgina Ansong, 2021).

Table 1 depicts the findings on the training and skills development needs of Dansoman market women. Ranking first with mean score of 4.07, standard deviation of 0.889 and variance of 0.709 was to the statement that "most women traders inherited the business from their parents and for that matter had no formal training whatsoever in financial management, marketing or customer care" and therefore require conventional training in those areas. The second ranking with mean score of 3.93, standard deviation of 0.708 and variance of 0.501 went to the statement that, "some women traders felt the need to help their husbands to support the family, thereby starting to sell on the market without formal training" these women therefore require help by way of building their capacity. The statement that "a few women felt they were not attracting husbands because of low education and poor financial circumstances so had to start selling as means of gathering some money with the view to enticing men as life partners" came third with mean score of 3.79, standard deviation of 0.865 and variance of 0.749. Such women also have to be helped to shore up their human capital. Ranking fourth with mean score of 3.64, standard deviation of 0.901 and variance of 0.811 was to the statement that "owing to low level of education, some women traders refuse to accept higher denominations of currency notes like the GH\$50.00, GH\$100.00, GH\$200.00 and for that matter will need training in basic mathematics". The statement that "some parents felt their daughters were not serious at school and therefore found some money to help them trade so as to irk a living without any training" came fifth with mean score of 3.57, standard deviation of 0.909 and variance of 0.826 . 


\subsection{Objective Two i.e. Exploring Avenues through Which Training Can Be Facilitated}

Presented in Table 2 are respondents' views on avenues through which training and skills development can be facilitated to shore up the capacity of traders.

Table 2 features the findings on avenues through which training needs can be implemented. Ranking first with mean score of 4.21, standard deviation of 0.561 and variance of 0.222 was to the statement that "there is the need to train and develop the skills of women according to their products segmentation". The statement that "there is the need to appeal to banks that do business with some small skill traders to help finance the organization of business clinics for their customers" came second with mean score of 4.08, standard deviation of 0.471 and variance of 0.645 . The third ranking with mean score of 4.00 , standard deviation of 0.538 and variance 0.289 went to the statement that "the local Dansoman branch of Ghana Union Traders Association (GUTA) should think of periodic training to help upgrade the skills of members so as to grow their businesses". Ranking fourth with mean score of 3.93, standard deviation of 0.803 and variance of 0.315 was to the statement that "government tax collecting agencies i.e. Ghana Revenue Authority (GRA) ought to assist small business owners with training packages so as to increase their profit margins and by extension pay

Table 2. Frequency table exploring avenues through which training can be facilitated.

\begin{tabular}{|c|c|c|c|c|c|}
\hline Statements & $\mathbf{N}$ & Mean & STD Dev & Variance & Rank \\
\hline $\begin{array}{l}\text { There is the need to train and develop the skills of women according } \\
\text { to their products segmentation. }\end{array}$ & 120 & 4.21 & 0.561 & 0.222 & 1 \\
\hline $\begin{array}{l}\text { There is the need to appeal to banks that do business with some } \\
\text { small skill traders to help finance the organization of business } \\
\text { clinics for their customers }\end{array}$ & 120 & 4.08 & 0.471 & 0.645 & 2 \\
\hline $\begin{array}{l}\text { The local Dansoman branch of Ghana Union Traders Association } \\
\text { (GUTA) should think of periodic training to help upgrade } \\
\text { the skills of members so as to grow their businesses. }\end{array}$ & 120 & 4.00 & 0.538 & 0.289 & 3 \\
\hline $\begin{array}{l}\text { Government tax collecting agencies i.e. Ghana Revenue Authority } \\
\text { (GRA) ought to assist small business owners with training packages } \\
\text { so as to increase their profit margins and by extension pay } \\
\text { more taxes to strengthen government financing. }\end{array}$ & 120 & 3.93 & 0.803 & 0.315 & 4 \\
\hline $\begin{array}{l}\text { The Metropolitan, Municipal and District Assemblies which } \\
\text { collect operating business permit fees from small business } \\
\text { owners must also support institutions financially to build } \\
\text { the capacity of small traders. }\end{array}$ & 120 & 3.79 & 0.945 & 0.893 & 5 \\
\hline $\begin{array}{l}\text { International poverty alleviation friendly NGOs like DANIDA, } \\
\text { Oxfam, USAID, JICA etc. should collaborate with local training } \\
\text { consultants to help build the capacity of these small women } \\
\text { business holders thereby broadening their business outlook, } \\
\text { and sustain if not improve upon their operational levels. }\end{array}$ & 120 & 2.56 & 1.338 & 1.791 & 6 \\
\hline
\end{tabular}

Source: (Georgina Ansong, 2021). 
more taxes to strengthen government financing". The statement that "the Metropolitan, Municipal and District Assemblies which collect operating business permit fees from small business owners must also support institutions financially to build the capacity of small traders" came fifth with mean score of 3.79, standard deviation of 0.945 and variance of 0.893 . Ranking sixth with mean score of 2.56, standard deviation of 1.338 and variance of 1.791 was to the statement that "International poverty alleviation friendly NGOs like DANIDA, Oxfam, USAID, JICA etc. should collaborate with local training consultants to help build the capacity of these small women business holders thereby broadening their business outlook, and sustain if not improve upon their operational levels".

\subsection{Objective Three i.e. Sensitizing Small Business Holders about the Need to Train}

Packaged in Table 3 are responses by way of participants' views on strategies for sensitizing them on the need to build their capacity to ensure successful business operations.

Table 3 features the findings in respect of strategies for sensitizing small business holders to accept training and skills development packages. Ranking first with mean score of 4.07, standard deviation of 0.597 and variance of 0.356was to the statement that "the women were made to understand that, training and skills development will broaden their knowledge and therefore assist them manage the business well". The idea that "the traders assimilated the fact that, training and development will enable them to network other persons within their supply chain in order to reduce operation cost" came second with mean score of 3.71, standard deviation of 0.886 and variance of 0.785 . The third ranking with mean score of 3.43, standard deviation of 1.122 and variance 1.260 went to the statement that "training and development will help them to understand the intricacies in banking operations so as to enable them benefit from

Table 3. Frequency table on sensitizing small business holders about the need to train.

\begin{tabular}{|c|c|c|c|c|c|}
\hline Statements & $\mathrm{N}$ & Mean & STD Dev & Variance & Rank \\
\hline $\begin{array}{l}\text { The women were made to understand that, training and skills } \\
\text { development will broaden their knowledge and therefore } \\
\text { assist them manage the business well. }\end{array}$ & 120 & 4.07 & 0.597 & 0.356 & 1 \\
\hline $\begin{array}{l}\text { The traders assimilated the fact that, training and development } \\
\text { will enable them to network other persons within their supply } \\
\text { chain in order to reduce operation cost. }\end{array}$ & 120 & 3.71 & 0.886 & 0.785 & 2 \\
\hline $\begin{array}{l}\text { Training and development will help them to understand the } \\
\text { intricacies in banking operations so as to enable them benefit } \\
\text { from more bank products and services. }\end{array}$ & 120 & 3.43 & 1.122 & 1.260 & 3 \\
\hline $\begin{array}{c}\text { Training will build their human capital thereby understanding } \\
\text { international business arrangement for attracting other } \\
\text { investors to expand operations }\end{array}$ & 120 & 3.25 & 0.963 & 0.899 & 4 \\
\hline
\end{tabular}

Source: (Georgina Ansong, 2021). 
more bank products and services". Ranking fourth with mean score of 3.25, standard deviation of 0.963 and variance of 0.899 was to the statement that "training will build their human capital thereby understanding international business arrangement for attracting other investors to expand operations".

\subsection{Objective Four i.e. Identifying Challenges Associated with Conducting Training for Dansoman Traders}

Shown in Table 4 are views from respondents concerning the objective of identifying challenges involving putting forward training packages to build the capacity of Dansoman traders, Ghana.

Table 4 depicts the findings on identifying challenges associated with conducting training and skills development activity for Dansoman traders. Ranking first with mean score of 3.22, standard deviation of 1.003 and variance of 1.007 was to the statement that "some women feel spending two or three days training will amount to loss of sales revenue and therefore will refuse to attend". The notion that "for training to be effective, it has to be made highly affordable if not free" came second with mean score of 3.00, standard deviation of 1.085and variance of 1.176. The third ranking with mean score of 2.94, standard deviation of 1.162 and variance 1.350 went to the statement that "owing to the fact that some traders have low level of education, there will be the need to organize some aspects of the training packages in suitable languages". Ranking fourth with mean score of 2.56, standard deviation of 1.338 and variance of 1.791 was to the view that "traders want incentives such as linking them up to financial institutions for

Table 4. Frequency table on identifying challenges with training Dansoman traders.

\begin{tabular}{|c|c|c|c|c|c|}
\hline Statements & $\mathrm{N}$ & Mean & STD Dev & Variance & Rank \\
\hline $\begin{array}{l}\text { Some women feel spending two or three days training will amount } \\
\text { to loss of sales revenue and therefore will refuse to attend. }\end{array}$ & 120 & 3.22 & 1.003 & 1.007 & 1 \\
\hline $\begin{array}{l}\text { For training to be effective, it has to be made highly } \\
\text { affordable if not free. }\end{array}$ & 120 & 3.00 & 1.085 & 1.176 & 2 \\
\hline $\begin{array}{l}\text { Owing to the fact that some traders have low level of education, } \\
\text { there will be the need to organize some aspects of the training } \\
\text { packages in suitable languages. }\end{array}$ & 120 & 2.94 & 1.162 & 1.350 & 3 \\
\hline $\begin{array}{l}\text { Traders want incentives such as linking them up to financial } \\
\text { institutions for soft loans prior to attending such training sessions. }\end{array}$ & 120 & 2.56 & 1.338 & 1.791 & 4 \\
\hline $\begin{array}{l}\text { Difficulty in getting consultants who can easily reduce terminologies } \\
\text { in financial management customer care, marketing management, } \\
\text { people management, succession plan etc. into the local languages } \\
\text { for the illiterate members of the traders. }\end{array}$ & 120 & 2.42 & 1.265 & 1.653 & 5 \\
\hline $\begin{array}{l}\text { Small business operators are not willing to join both social security } \\
\text { schemes and micro insurance schemes as means of insuring their } \\
\text { lives and business respectively. }\end{array}$ & 120 & 2.38 & 1.326 & 1.759 & 6 \\
\hline
\end{tabular}

Source: (Georgina Ansong, 2021). 
soft loans prior to attending such training sessions". The fifth ranking with mean score of 2.42, standard deviation of 1.265 and variance of 1.653 was the statement that "difficulty in getting consultants who can easily reduce terminologies in financial management customer care, marketing management, people management, succession plan etc. into the local languages for the illiterate members of the traders". The view that "small business operators are not willing to join both social security schemes and micro insurance schemes as means of insuring their lives and business respectively" came sixth with mean score of 2.38, standard deviation of 1.326 and variance of 1.759 .

\section{Discussion of Findings}

Discussions with the financial institutions pointed out that, the traders usually come in for short term funds especially overdrafts nut often fail to pay within the stipulated time owing to what they describe as poor sales and not meeting their sales targets. The banks small business officials visit them in the market, to assess their challenges and often note that, some of them spend more than they make and for that matter they often end the day with deficits which invariably go to erode their working capital base. The bank operates the cash pick up system for some of them and for that matter, by $4 \mathrm{pm}$ each working day, and Saturdays, officials go with the bank van to mock up funds which are credited to their balances at the bank.

The bank also render advisory services, and often warn the traders against using revenue in procuring capital items like parcels of lands and vehicles instead of employing medium term finance from the banks. Besides business loans the traders also go in for funding for paying rent advance for the shops as well as their dwelling places at home. Some banks like Ghana Commercial Bank (GCB), Barclays (now ABSA), Standard Chartered Bank and Universal Merchant Bank (UMB) do organize training sessions with the small business rollers as a way of shoring up their capacity in transacting bank businesses, customer care and marketing. From Table 1, it can be gathered that, Dansoman small business holders actually need training and skills development in order to assist them compete properly but that, such training sessions ought to be made highly affordable and instructions organized in a language that will go down well with most of the traders. A good number of them are aware that a training session is really a requisite tool for expanding their operations but have not been able to access them for various reasons. The study therefore came in at the right time to sensitize them on the need to receive training and how the sessions can be held to assist them build their small business holdings as display in Tables 1-4.

The first objective of the study in Table 1, examined the training and skills development needs of the small business holdings of women in Dansoman market of Accra. It came out unequivocally from the study that, most women traders inherited the business from their parents and for that matter had no formal trading whatsoever in financial management, marketing or customer care. This 
view is supported by Mensah (2013) who also studied SMEs in Africa and noted that a good number of these traders took after the business from their parents just as is the case in some advance countries where family business have span over centuries.

The findings that, some women traders felt the need to help their husbands to support the family, thereby starting selling on the market without formal training has also been corroborated by Ayodeji (2015) who pointed out that uncertainties in matrimonial relationship often necessitate the need for both spouses to be economically viable. The source continues that a bread winner may die leaving the children and wife with very little to live on, and in the process making life virtually unbearable for his dependents.

The findings that a few women also felt they were not attracting husbands because of low education and poor financial circumstances so had to start selling as means of gathering some money with the view to enticing men, was also implied by Bakker (2017) who noted that, men now want wives who are solvent so as to together bring them a family under less stressful conditions. The source rather encouraged parents to educate their daughters to be career women so as to afford them a better opportunity of attracting men of their choice.

The discovery that owing to low education, some women traders refuse to accept higher denominations of currency notes like the GHథ50.00, GH\$100.00, $\mathrm{GH} 200.00$ owing topoor mathematical faculties needed to strike the change came as a surprise to the researcher, although Mensah (2013) also made mention of this facts in his study on the growth and dynamics of SMEs. The source noted further that such traders shy away from these high currencies owing to problems with calculating the change to be administered to complete the transaction.

The findings that some parents felt their daughters were not serious at school and therefore found some money to help them trade so as to irk a living was seen by Ayodeji (2015) as a common phenomenon in most African countries. He therefore advised parents to encourage their children to learn vocations rather than selling wares or materials that they have very little knowledge.

The second objective as depicted in Table 2, sought to explore avenues through which training needs can be administered to the identified needy market women and it came out that there is the need to train and develop the skills of women according to their products segmentation. This way, the woman will be more conversant with the marketing and other supply chain management arrangement within their field occupation. This view has also been articulated by Eniola \& Entebang (2014) who argue that, essentially, market women must have a fair idea on the marketing and distribution arrangement associated with the products they deal in. This, the source explains will enable them shore up their capabilities and selling these products thereby enhancing their sales volumes and by extension make adequate profit to strengthen their business equity.

Another finding had to do with the need to appeal to banks that do business 
with some small skill traders to help finance the organization of business clinics for their customers. This idea of business clinic has been discussed extensively by Idawatil et al. (2016) who pointed out that, under such training packages the traders who may be semi-literate can pick ideas that will boost their knowledge base in the administration of the products in the market. The co-authors maintained that banks are the key development partners of the traders and for that matter, financing such capacity building sessions will only help the traders to sell more and route more funds through the banks thereby establishing a win-win situation. This is to say that by passing a lot more funds through the banks traders will invariably be enhancing the liquidity position of the banks and this would enable them to learn more and expand their business horizon.

The study also found out that, the local Dansoman branch of Ghana Union Traders Association (GUTA) should think of periodic training to help upgrade the skills of members so as to grow their businesses. This is to say that the traders' own business leaders must see the need to build the capacity of members and for that matter, they could lobby stakeholders for requisite funding to organize such skills building sessions for the traders. Ikupolati et al. (2017) share this view and noted that, trade unions owe it a duty to educate the members on strategies for building their capacity in order to grow their businesses as a way of helping to improve the per capita income of their countries. The source maintained that, the trade association executives also received affiliations and periodic contributions part of which can be channeled to help broaden the knowledge scope of their members. As one of his objectives, GUTA believes in engaging the government on behalf of their members towards augmenting their business practices, and training constitutes and important component in any attempts to augment the business practices of small holder traders.

The study further revealed that, government tax collecting agencies i.e. Ghana Revenue Authority (GRA) ought to assist small business owners with training packages so as to increase their profit margins and by extension pay more taxes to strengthen government financing. It is regrettable according to Idawatil et al. (2016) that although revenue collecting agencies in the sub-Saharan Africa mainly copy and operate Western kind of tax administration, they fail to realize that, in the Western world, there is a Small Business Authority (SBA) whose duty it is to help small businesses grow through marketing, financial, people management training packages thereby strengthening their structures and put them on the part of growth to enhance constant flow of funds from these small businesses by way of taxation.

In Ghana for instance, Mensah (2013) criticize the Ghana Revenue Authority (GRA) for being only interested in collecting money rather than ensuring that other agencies are put on board to help the small businesses to grow. The source noted that, in 2009 , more than $55 \%$ of small businesses that registered to pay Value Added Tax (VAT) collapsed within 3 years and therefore fail to turn up to pay this domestic tax which had already been factored into government esti- 
mated tax revenue for the various years. Lancaster and Di Milia (2014) also criticized sub-Saharan government for showing less interest in the business growth activities of the small tax payer and noted that, there is the need for "responsible taxation" which was explained to mean government taking key interest in the well-being of businesses in order to ensure study flow of anticipated revenues.

It came out from the study unequivocally that, the Metropolitan, Municipal and District Assemblies which collect operating business permit fees from small business owners must also support institutions financially to build the capacity of small traders. This way such businesses can continue to stabilize their operations in order to continue paying business permit fees necessary for the upkeep of the assemblies. This is corroborated by Lancaster and Di Milia (2014) in their paper on the need for government and it agencies to pay particular interest in the business growth of small holder traders. This source is of the strong conviction that close monitoring of the state through financial injections in times of difficulties will go a very long way to establish a mutually beneficial relationship since when the traders make good profit, obviously, the tax element and levies to state agencies will also go up in quantum.

The study further uncovered the fact that, international friendly poverty alleviation NGOs like Danish International Development Association (DANIDA), UK Oxfam, USAID, Japanese International Corporation and Assistance (JICA) etc. should collaborate with local training consultants to help build the capacity of these small women business holders thereby broadening their business outlook, and sustain if not improve upon their operational levels. Already, the German GTZ has been collaborating with the NBSSI over the years to build the capacity of small scale manufacturers. The American TECNOSERVE has also been assisting local manufacturers in polishing their packaging aspect of their production processes and this is helping them to add value to their products and in the process increase their production prices for the growth of their profit curve (Littlewood and Holt, 2018).

The third objective in Table 3, sought to investigate the awareness of the traders in respect of the importance of training and skills development to their occupation. The study inculcated in the minds of the traders that, training and skills development will broaden their knowledge and therefore assist them manage the business well. This view has been corroborated by a good number of papers like Mamabolo et al. (2017) \& Montani et al. (2014) who all expressed the key importance of training development to business growth. In the opinion of Mamabolo et al. (2017) training and skills development constitutes an indispensable aspect of a business growth. It is for this reason that small business holders must undertake some capacity building sessions in order to broaden their knowledge on the kind of business they dealing in. Training according to Montani et al. (2014) exposes the trader to a new ways of doing things in the industry. This way, spoilages, breakages, issues resulting in customer's dissatisfaction etc. will all be eschewed leading to the practice of modern management 
techniques necessary to win a fair share of the market.

The traders were made to understand that, training and development will enable them to network other persons in the supply chain in order to reduce operation cost. This view has been developed by Muller et al. (2015) who noted that, some forward looking banks operates business clinics and at the end of such programs, they convince small business owners in similar trade to combine their capital and buy in bulk from suppliers especially those in the Far East. These banks, according to the source, pre-finance some of these business enhancement proposals and facilitate the trip to Asia for expanding the operational scope of their trader customers of the bank. By buying in bulk, these traders are able to reduce cost of purchases and by extension operation cost necessary to enhance their profit levels. Some, the source adds make friends and sometimes discuss ways of disposing off wares especially when they are of different geographical locations.

The study also pointed out that, training and development will help them to understand the intricacies in banking operations so as to enable them benefit from more bank products and services. This view is shared by Salas et al. (2012) who noted that, in the event of banks organizing business clinics for traders, the opportunity is created for the banks to expose the traders to most of their products and services and this again go a very long way to help build a mutually beneficial relationship between the banker and the small trader. Some traders according to Littlewood and Holt (2018) share traditional beliefs that, a trader should not accept external loans and that should continue leveraging equity in order to avoid the payment of high interest rate. This view is unfortunate according to this source and notes that, the banks only invest in one's business with loans and therefore it is fair to share the profits with them through interest payment. The banks through such periodic external injections facilitate the growth of the business rather than relying solely on the equity which may grow but slowly.

The fourth objective as portrayed in Table 4, identified the challenges associated with conducting training and skills development activities to shore up the managerial skills of Dansoman Women Traders and discovered that, some women feel spending two or three days training will amount to loss of sales revenue and therefore will refuse to attend. This view was sharply criticized by Eniola \& Entebang (2014) who noted that, closing one's shop or business up to a week could have a multiplier positive effect on the business in the long term and therefore traders must be oriented with these facts in order to accept training as an indispensable part of business growth. It is through such sensitization that, traders will come to term with relevance of training and avail themselves of the opportunity to build their business. Ikupolati et al. (2017) is of the conviction that, when traders who had gone through training and are successful are made to tell such success stories, their colleagues will be enticed to shut their shops for a fee days in favor of capacity building. 
The study found out that, for training to be effective, it has to be made highly affordable if not free. This view was also articulated by Mensah (2013) who noted that, one huge hindrance to building the capacity of traders, some of whom are semi-literates, will be the high admission fee and therefore suggested that, stakeholders especially the banks, relevant government agencies and friendly non-profit organizations should collaborate and fund such empowerment training sessions for small business holders.

The study further revealed that, owing to the fact that some traders have low level of education, there will be the need to organize some aspects of the training packages in suitable training packages. The issue of medium of expression at such capacity project is very essential in the views of Lancaster and Di Milia (2014) who pointed out that, organizing a training session in a white man's language may not be suitable for a large number of small business holders most of whom computer schooling at various basic level or received no schooling at all. The source further noted that, given the tide of inequalities in terms of economic opportunities, in the social system of sub-Saharan Africa, it is only logical that a good number of people after very basic education will take to buying and selling to irk a living. This makes it mandatory for appropriate local languages to be adopted in running the training sessions. In Ghana, Mensah (2013) noted that, languages like Twi, Ga, Hausa and Ewe are well developed and therefore can be used as medium of expression for various training sessions organized at various geographical locations. The Volta Region will use Ewe while the Northern Region will adopt Hausa. The Greater Accra region can use Ga or Twi since both are well spoken languages in these areas. Ashanti region is predominantly a Twi locality and therefore this language should be employed.

The study revealed other challenges like traders wanting incentives such as linking them up to financial institutions for soft loans in order to attend such training sessions as well as the difficulty in getting consultants who can easily reduce terminologies in financial management customer care, marketing management, people management, succession plan etc. into the local languages for the illiterate members of the traders.

The study also found it difficult convincing small business operators to join both social security schemes and micro insurance schemes as means of insuring their lives and business respectively. These findings have been corroborated by Littlewood and Holt (2018) who expressed disappointment of some insurance companies in failing to live up to expectations when it is time to honour their portion of the insurance contracts. The source further criticized social security outfit which doll out almost peanut to lower income workers and for that matter did not appear to be attractive to the market women as means of protecting their future livelihood. In the opinion of Mamabolo et al. (2017), given the importance of social security and insurance, it is essential that government creates the environment for the self-employed small traders to participate in the various schemes towards securing their future. 


\section{Conclusions and Recommendations}

The issue of training and skills development for traders is long overdue and for the matter stakeholders should endeavour to get round and plan an effective way of enhancing the skills of the small business holders. If the traders are well trained, business scope would expand leading to more revenue and by extension profit upon which high amount of taxes would be pain to the government while the local authorities will be entitled to their business operating permits fees and other levies. The banks are likely to receive more funds from the traders thereby augmenting their working capital base while the traders themselves will have their living standards improved and the process send their children to better schools, acquire some properties and logically as it were enhance the per-capita income levels of the country.

Issues which are likely to be hindrances to the training like admission fees, language of instruction etc. can adequately be catered for with the view to encouraging a large segment of these traders to accept training as an indispensable part of their business growth. Government should also consider it as a matter of agency to establish the American version of Small Business Authority (SBA) which will liaise with agencies like the NBSSI to see to the general well-being of small traders in the countries. The small trader segment of the commercial environment really creates jobs for a large segment of the people notably single mothers and for that matter, every facility especially training must be taken serious towards helping them to grow their businesses as a strategy for improving national economic growth indicators.

\section{Acknowledgements}

Special thanks go to the local executives of Ghana Union Traders Association (GUTA) of Dansoman Market especially Edward Oduro, Edwin Tetteh and Sylvia Yorke for their initial support in facilitating the interaction with the traders with the various departments of the market. Some bank managers in Dansoman area notably the Standard Chartered Bank, Ghana Commercial Bank (GCB), Agric Development Bank (ADB), Zenith Bank and Stanbic Bankdeserve special mentioning for providing useful information which assisted in strategizing the directions of the study.

\section{Conflicts of Interest}

The author declares no conflicts of interest regarding the publication of this paper.

\section{References}

Ayodeji, M. A. (2015). Entrepreneurial Development Barriers in a Developing Nation: A Case Study of the Nigerian Printing SMEs. Master's Thesis Masters of Business Administration Business Management and Entrepreneurship Visamäki Spring.

Bakker, A. B. (2017). Strategic and Proactive Approaches to Work Engagement. Organi- 
sational Dynamics, 46, 67-75. https://doi.org/10.1016/j.orgdyn.2017.04.002

Bauer, J. (2007). Few Area Businesses Owned by Women. The Grand Rapids Press, December 26.

Bell, B. S., Tannenbaum, S. I., Ford, J. K., Noe, R. A., \& Kraiger, K. (2017). 100 Years of Training and Development Research: What We Know and Where We Should Go. The Journal of Applied Psychology, 102, 305-323. https://doi.org/10.1037/apl0000142

Cardon, M., \& Valentin, S. (2017). Training and Development in Small and Medium Enterprises. In K. Brown (Ed.), The Cambridge Handbook of Workplace Training and Employee Development, (Cambridge Handbooks in Psychology) (pp. 363-382). Cambridge: Cambridge University Press. https://doi.org/10.1017/9781316091067.018

Cho, Y., \& Honorati, M. (2014). Enteroreneurship Programs in Developing Countries: A Meta-Regression Analysis. Labour Economics, 28, 110-130. https://doi.org/10.1016/j.labeco.2014.03.011

Daft, L. R. (2006). The New Era of Management. Thompson South: Western Publishers.

De Jong, J., \& Den Hartog, D. (2010). Measuring Innovative Work Behaviour. Creativity and Innovation Management, 19, 23-36. https://doi.org/10.1111/j.1467-8691.2010.00547.x

Eniola, A. A., \& Entebang, H. (2014). SME Firms Performance in Nigeria: Competitive Advantage and Its Impact. International Journal of Research Studies in Management, 3, 75-86. https://doi.org/10.5861/ijrsm.2014.854

Grossman, R., \& Salas, E. (2011). The Transfer of Training: What Really Matters. International Journal of Training and Development, 15, 103-120. https://doi.org/10.1111/j.1468-2419.2011.00373.x

Idawatil, I., Mahmud, A., \& Dirawan, G. D. (2016). Effectiveness of Training Model Capacity Building for Entrepreneurship Women Based Empowerment Community. International Education Studies, 9, 142-150. https://doi.org/10.5539/ies.v9n11p142

Ikupolati, A. O., Medubi, R. D., Obafunmi, M. O., Adeyeye, M. M., \& Oni, E. O. (2017). Small and Medium Enterprises (SMEs) as a Source of Human Capacity Building in Nigeria. Journal of Small Business and Entrepreneurship Development, 5, 35-42. https://doi.org/10.15640/jsbed.v5n1a4

Lancaster, S., \& Di Milia, L. (2014). Organisational Support for Employee Learning: An Employee Perspective. European Journal of Training and Development, 38, 642-657. https://doi.org/10.1108/EJTD-08-2013-0084

Li, X. G. (2012). Training and Developing. Hengshui: Hengshui University.

Littlewood, D., \& Holt, D. (2018). Social Entrepreneurship in South Africa: Exploring the Influence of Environment. Business and Society, 57, 525-561. https://doi.org/10.1177/0007650315613293

Mamabolo, M. A., Kerrin, M., \& Kele, T. (2017). Entrepreneurship Management Skills Requirements in an Emerging Economy: A South African Outlook. Southern African Journal of Entrepreneurship and Small Business Management, 9, 1-10. https://doi.org/10.4102/sajesbm.v9i1.111

Mensah, S. (2013). A Review of SME Financing in Ghana. The UNIDO Regional Workshop of Financing SMEs, Accra, 2 March 2013, 28-45.

Montani, F., Odoardi, C., \& Battistelli, A. (2014). Individual and Contextual Determinants of Innovative Work Behaviour: Proactive Goal Generation Matters. Journal of Occupational and Organizational Psychology, 87, 645-670.

https://doi.org/10.1111/joop.12066

Muller, P., Caliandro, C., Peycheva, P., Gagliardi, D., Marzocchi, C., Ramlogan, R., \& 
Cox, D. (2015). Annual Report on European SMEs 2014/2015. Brussels: European Commission.

Ongori, H., \& Nzonzo, J. C. (2011). Training and Development Practices in an Organisation: An Intervention to Enhance Organizational Effectiveness. International Journal of Engineering and Management Sciences, 24, 187-198.

Salas, E., Tannenbaum, S. I., Kraiger, K., \& Smith-Jentsch, K. A. (2012). The Science of Training and Development in Organisations: What Matters in Practice. Psychological Science in the Public Interest, 13, 74-101. https://doi.org/10.1177/1529100612436661

Thom, D. (2015). An Exploratory Study into Entrepreneurial Motivation in Changing Contexts. PhD Thesis, Wellington: Victoria University of Wellington.

Yang, I., Chang, M., \& Kim, N. (2005). Policies on Facilitating Startups of Enterprises by Specialized Female Resources. Women's Studies Forum, No. 21, 71-78. 